\title{
Rural Community About Adequate Standards of Living
}

\author{
Nunuk Nuswardani* \\ Faculty of Law \\ Trunojoyo University Of Madura \\ Bangkalan, Indonesia
}

\author{
Wartinigsih \\ Faculty of Law \\ Trunojoyo University Of Madura \\ Bangkalan, Indonesia \\ aprilina.pawestri@trunojoyo.ac.ic
}

\begin{abstract}
Cultural rights are human rights related to economic, social and cultural aspects, one of which is the 'right to an adequate standard of living'. The 1945 Constitution and the Law regulate matters related to these cultural rights, specifically the focus of this study, namely on the right to adequate standard of living. Further regulations have also been issued, including regional regulations. The problem is how local governments regulate the right to an adequate standard of living for the community, especially in rural areas. If there is also law that regulates it, is it synchronous with policies issued in the regions so that it can be implemented to the rural community? To answer these questions, a research on legal materials was carried out using the statute approach and the conceptual approach. The analysis results of legal materials were found that: there were three types of regulatory policies on 'the right to adequate standard of living', namely, first, protection of economic rights, second protection of social rights, third protection of cultural rights. The problem that often arises in the community was about the difficulty of implementing the regulation of the cultural rights of rural communities regarding adequate standard of living in terms of the economic, social and cultural aspects. The implementation of the regulation depended on the political will of the stakeholders in the region considering the availability of policies at the central level is quite complete. Therefore, solutions must be made to restructure the implementation of adequate standard of living in more clear and detailed manner for the sake of the creation of rural communities whose constitutional rights have been fulfilled.
\end{abstract}

Keywords: cultural rights, adequate standard of living, government policies, rural communities

\section{INTRODUCTION}

The right to adequate standard of living as the study main issue is an adage not only regulated in laws and regulations, but should also be implemented in people life. The right to adequate standard of living, as discussed in various literature since the era of John Locke until now, is part of cultural rights and cultural rights in general are part of human rights. Human rights have characteristics: irrevocable, indivisible, intrinsic and universal [1]

Human rights which is specifically in this review include cultural rights, including the ability of groups to preserve their culture, raise children in accordance with the ways of their ancestors, restore their language, and not be deterred from their economic base by the country in which they belong [2]. Experts agree that cultural rights are doctrines about certain rights which are not obtained by individuals or individuals, but by groups that can be identified, such as ethnic groups, indigenous communities or rural communities.

The Universal Declaration of Human Rights recognizes the existence of economic, social and cultural rights, as referred to in the International Covenant on Economic, Social and Cultural Rights. In addition, there are also several conventions that recognize specific sociocultural economic rights, such as:

1) The Convention on the Rights of the Child and the Convention on the Elimination of All Forms of Discrimination against Women recognizes and protects the economic, social and cultural rights of children and women.

2) The International Convention on the Elimination of All Forms of Racial Discrimination prohibits discrimination based on race or ethnicity related to the fulfillment of a number of economic, social and cultural rights (although the prohibition is also contained in other human rights treaties).

3) The Convention on the Rights of Persons with Disabilities also prohibits discrimination on the basis of disability, including the rejection of appropriate accommodation [3]

The economic, social and cultural rights contained in these cultural rights must be assessed in terms of the right to adequate standard of living, because adequate standard is minimum limit for group of people to have reasonably good economic, social and cultural life.

In various studies on the community (especially the rural community), it is often found that the inadequate standard of living exists in the rural community life. There is always an imbalance between the three standards, very few are found in adequate side of life that is economically, socially and culturally balanced in village community group. Even if the economic life of rural community advances, then the social and cultural side is left behind and vice versa happens in other village communities.

Therefore, the purpose of this study is to explore deeper into how government policies regulate and preserve cultural rights regarding a adequate standard of living for rural communities.

\section{RESEARCH METHOD}

Research that was conducted related to this study used statutory approach and conceptual approach. The statute approach was used because the legal issues raised 
stem from the importance of issuing norms in the context of efforts to preserve the cultural rights of rural communities regarding an adequate standard of living. The conceptual approach was used as basis for developing arguments related to a decent standard of living as long as it is regulated and implemented in Indonesia..

\section{RESULT AND DISCUSSION}

Basic understanding of 'human rights', put forward by Jack Donnelly [1], among others, states that human rights are the basic texts for those who study all fields of human rights. Donnelly's opinion leads to the main premise that human rights are the same, irrevocable, and universal, even with cross-cultural considerations of 'relativism'. In this case human rights are 'not relative' culturally because culture is not a cause or factor in the development of human rights ideas and practices and does not have to be for or against certain human rights. Donnelly stated, "There is no specific comprehensive culture or doctrine that is naturally compatible or incompatible with human rights. This is a matter of what certain people and communities create and do with their cultural resources. Culture is very easy to forge ... "(p.107). Donelly's study uses examples from various countries, cultures and points in history, which support his argument about universal rights versus cultural relativism.

With regard to Donelly's opinion, the culture of rural communities in Indonesia, which has the characteristics of each ethnic group, certainly affects its economic and social life, for example: social life that is cultured in trade often makes certain rural communities better off their economic side than other rural communities. Therefore, in order to provide guidelines for decent standard of living $\mathrm{s}$ for rural communities of various ethnic groups in Indonesia, the government is obliged to issue policies, regulations and preservation of the cultural rights of rural communities to be maintained. Need law as social engineering.

The law in its social engineering function is intended to make changes in society. Close supervision of several laws that allow land clearing by burning and the resulting economic, social and health impacts demonstrate the important role of law in its social engineering function [4] . Furthermore, Nunuk and Wartiningsih implement the law as social engineering in handling cases of forest burning for land clearing. The important role of government in creating a balance between society and its environment is evident from the policies and regulations it publishes.

William Easterly, in his book The Tyranny of Experts [5] states that development ideas mainly emerge with discriminatory foundations, West-centric: "Discovering the formative years of development between 1919 and 1949 highlights a tipping point: development ideas formed before even there is the least respect in the West for Western countries. " individual rights at rest "(p. 44). Easterly specifically criticized large international organizations and Western-based development ideals as the cause of the problem because of their strategy for economic development in countries ruled by authoritarian dictators. In particular, Easterly strongly rejects the strategy of supporting authoritarian rulers and dictators to improve the economy and reduce poverty. The argument is that the rights of the poor, especially economic and political rights, are ultimately more important for their well-being and for their development than for their material well-being. He states, "That does not mean that we do not too concern with material suffering; it means that we understand that autocrats have offered false offers to meet material needs while we ignore the suppression of their rights "(p. 339). Easterly offers developmental and human rights workers a unique and challenging perspective, driving change in ways of thinking about human freedom and human development. The government as a development worker is obliged to issue policies or regulations that pay attention to aspects of poverty alleviation not by means of a dictator, but pay attention to balance, humanity and unity.

Regarding the implementation of rural communities rights, Nunuk and Wartiningsih stated that with autonomy, the implementation of cultural rights related to an adequate standard of living in rural communities (especially forest rural communities) was less than optimal. This is because the implementation of autonomy does not take root and touches the rural community[4].

Regulatory policies regarding 'the right to adequate standard of living' in Indonesia are regulated in various laws and regulations. The types of regulations regarding adequate living standards are divided into:

a. Regulations on protection of economic rights:

b. Regulations on protection of social rights,

c. Regulations on protection of cultural rights.

The right to adequate standard of living in the understanding and regulation of human rights (HAM) as stipulated in the human rights law was divided into three details of human rights, namely:

1) Civil and political rights,

2) Economic, social and cultural rights, and

3) Rights in development.

These rights have relationship to maintain the balance of people's lives and cannot be separated from one another. Fulfillment of civil and political rights cannot run well without the fulfillment of economic, social and cultural rights, as well as the right to development. Indonesia is bound by international law as the fulfillment of economic and social rights for the people of Indonesia[6] .

At The Hague Conference 2019, the conference with the theme "Economic, Social, and Cultural Right in An Age of Exit", Constitutional Justice of the Republic of Indonesia, Palguna, explains that: Inclusion of economic, social and cultural rights in the Indonesian constitution is outlined in the Preamble of the 1945 Constitution. In the fourth paragraph of the Preamble it is stated that one of the objectives of the establishment of the Indonesian nation is to realize social justice for all Indonesian people [7].

In 1999, to advance human rights especially economic, social and cultural rights, and show concern for the Indonesian people, an amendment was carried out by including in more detail human rights in the changes to the 1945 Constitution. It contains the right to form family and continue descendants through legal marriage, the right to life and growth, the right to protection from discrimination and violence and the right to basic education. In addition, the constitution also provides obligations to the state to fulfill the constitutional rights of citizens relating to economic, social and cultural rights. In this case, for 
example, the state is obliged to finance the basic education of every citizen by requiring all citizens to attend the basic education. Another example is the state obligation to develop social security system for all Indonesian people to be one part that the Indonesian nation upholds the protection of human rights, especially economic, social and cultural rights.

To provide protection for these rights, then, if there are provisions in the law that are contrary to the constitution, the law must be declared unconstitutional and therefore not valid according to law. This is what happened in Indonesia after the amendment of the 1945 Constitution. The presence of the Constitutional Court (MK) in the Indonesian constitutional system is to maintain the protection of human rights contained in the constitution. So that if there are citizens who consider a law contrary to the 1945 Constitution, then it can be tested through judicial review process in the Constitutional Court[7].

Examples of judicial review of laws which are considered detrimental to the constitutional rights of the community have been severed by the Constitutional Court, including:

1) Testing the Electricity Law: The provisions in the Electricity Law contained the concept of unbundling, the state does not interfere in its implementation in the community, so the state was deemed unaware if the concept of unbundling is detrimental. In its decision, the Constitutional Court views that the concept of the state cannot interfere in the matter of electricity in conflict with Article 33 paragraph 2 of the 1945 Constitution which stated that production branches were important to the state and affect the livelihoods of many people (in this case electricity ) should be controlled by the state so that the state cannot be neglected and not be responsible for it.

2) Testing the Marriage Law: In its provisions, the Marriage Law regulates the marriage age limit for women of at least 16 years. The court considered that women aged 16 years should still enjoy their constitutional rights to obtain education, health services and avoid discrimination and violence. Thus, the Constitutional Court ruled that the provisions on the age limit of 16-year-old women to get married were contrary to the Constitution. Then the Constitutional Court's decision, followed up by the Government together with the Parliament by including the issue of the marriage age limit became the agenda of National Legislation Program to make changes in the Marriage Law.

Thus, the existence of Judicial Review process at the Constitutional Court showed that Indonesia is constitutional democracy that is serious about protecting human rights in this case the constitutional rights of citizens. Because to be considered as constitutional democracy state, the main requirement that Indonesia must fulfill is the fulfillment and protection of human rights.
However, the main highlight of the problem that often arises in the community was the difficulty of implementing the regulation of the cultural rights of rural communities regarding the decent standard of living from an economic standpoint. The actual implementation of the regulation depended on the political will of the authorities in the region considering the availability of policies on the economy of the village community is quite complete.

Whereas regulations relating to adequate standard of living already exist in various laws and regulations at the central level both in the Law, Government Regulation, Presidential Regulation / Decree and Regional Regulation. However, all of these arrangements are still hampered by their implementation. To overcome the problem of implementing adequate standard of living in the life of the rural community, what can be done by the Regional Government is to identify the problem and arrange for matters that have not been regulated immediately to make regulatory policy as a means of implementing the relevant rules, in dealing with implementation problems of adequate standard of living, with the following analysis:

\section{Functions of Law as a Tool of Social Engineering}

Law in its social engineering function is intended that law is able to make changes in society. Oversight by the national commission on the implementation of several laws and regulations on human rights by the government, both central and regional, does not seem to have touched on the issue of defense of essential rights for rural communities. The impact of the economic, social and health arrangements produced so far shows the important role of law in its social engineering function. Therefore, there is no doubt that government officials, especially law enforcement officers, continue to think that is embedded in formal legalism, so that it can be understood that the administration of government is always guided by the applicable laws and regulations.

\section{Implementation of Decent Living Standards in the Regions}

The real conditions in society showed, the view that law could shape and change the conditions of society has long been put forward in the theory of "law as a social engineering tool" from the Resounding Pound, which later, in this theory was also developed in Indonesia. The law in this case is regulation by the government. The steps in social engineering are systematic, from identifying problems to finding solutions.

In the context of government regulation as a social engineering tool, this regulation influences community groups to form the desired type of community group. Thus, there is a need to plan the desired form of community. The form of community that is desired is realized by the direction of the policy determined by the rule of law by the government.

According to Satjipto, in using law in its function as a social engineering tool the existing problems must be identified as well as possible, including recognizing the targeted community for the arrangements and values that exist in that society[8]. In this case the fulfillment of cultural rights in the form of the right to an adequate standard of living for rural communities, as stipulated in the 
constitution. The law can function as an instrument used consciously to achieve certain goals. However, the process will last quite a long time and the effect can be a chain that is interrelated with one another. Law, which in this case is understood as a regulation made by the regional government, is expected to produce the effect of changes in people's lifestyles in terms of economy, socio-political life and culture in accordance with the conditions of each region. The change is due to the arrangement in the regulation, which is also expected to increase income and welfare of the community, which in turn is able to develop better social and cultural life as well.

\section{CONCLUSION}

The regulation model by the regional government based on adequate standard of living for rural communities, as established by the constitution will guarantee the preservation of their cultural rights. This is due to the existence of these regulatory norms which will have impact on changing society to be more just and prosperous which then impacts on the change of social and cultural life for the better. In addition to applying the constitution, laws and other regulations below it, the regulations by the regional government must also be clearer and more detailed and refer to local wisdom, so that their existence will benefit from various aspects of community life both in terms of economic, social and cultural aspects for rural communities.

\section{REFERENCES}

[1] J. Donnelly, Universal Human Rights in Theory and Practice, 3rd Ed. USA: Cornell University Press, 2013.

[2] S. Tan, termwiki, terms, translator / interpreter Tanjung Pinang, Indonesia. Tanjung Pinang: interpreter Tanjung Pinang, Indonesia., 2015.

[3] A. Leckie, Scott; Gallanger, Economic, social and cultural rights: a legal resource guide. USA: University of Pennsylvania Press, USA, 2006.

[4] M. W. Nunuk Nuswardani, "The Handling of Cases of Forest Fire Using the Model of Progressive Interpretation of Law," 2018.

[5] W. Easterly, The Tyranny of Experts: Economists, Dictators, and the Forgotten Rights of the Poor. NYU, USA: Basic Books, 2015.

[6] K. Mudjarab, Human rights: Economic, social and cultural rights (Right for decent life). Yogyakarta: Muhammadiyah University Yogyakarta, 2019.

[7] Mahkamah Konstitusi, "MK and Protection of Economic, Social and Cultural Rights," Mahkamah Konstitusi Official Website, 2019. .

[8] S. Rahardjo, Ilmu Hukum. BANDUNG: Citra Aditya Bakti, 2000. 